\title{
Teaching Behaviours among the Primary Physical Education Student Teachers in Hong Kong 香港小學體育㚹訓學生的教學行為
}

\author{
Alberto Cruz \\ Department of Physical Education \& Sports Science, \\ Hong Kong Institute of Education, HONG KONG \\ 高薘倫 \\ 香港敉育學院體育及運動科學系
}

\begin{abstract}
The purpose of the study was to describe the teaching behaviours of Hong Kong physical education student teachers. Thirty-two local pre-service and in-service student teachers were videotaped teaching two lessons in their own schools or in the allocated school during their final practicum. Each videotaped lesson was coded using the Physical Education Teacher Assessment Instrument (PETAI). Data generated by the PETAI were entered into a SPSS programme to produce further statistical analysis. The results were comprehensive described and comparison were made between the in-service and pre-service student teachers' behaviour categories by employing the independent t-test. Results indicated that the in-service student teachers had significantly higher percentages of the response presentation and the total teacher instructional time than the pre-service group. Whilst the pre-service student teachers spent significantly more time in planned presentation, equipment management, organization, behaviour management and overall management time than the in-service group. It is likely the different experience in physical education lesson teaching in school environment of the groups give account for the differences of their teaching behaviours. Findings of the present study implied that there were different teaching behaviour patterns and needs of pre-service and in-service student teachers during their practicum.
\end{abstract}

\section{摘 要}

本研究目的是探討香港體育師訓學生的教學行為。三十二位職前及在職師訓學生在任敉學校攝錄兩節體育課。研 究採用「體育教師評估工具 (PETAI)」分析每敉節的敎學行為。獨立樣本 $\mathrm{t}$-test 顯示職前及在職師訓學生在體育課中的指 導及管理時間上有顯著差異。在職師訓組較職前師訓組多利用時間對學生學習回應 (Response Presentation)，而職前師訓 組則較在職師訓組多分配時間於內容演譯(Planned Presentation)、器材管理(Equipment Management)、活動組織 (Organization) 及學生行為管理 (Behaviour Management)，此等差異可能是他們有不同體育教學經驗所致。

\section{Introduction}

Students learn in classroom but this may not be intended. Educators describe effective teaching as teaching results in intended learning (Berliner, 1987; Rosenshine, 1987). Teachers are therefore responsible and expected to produce intended learning in school. Physical education teachers are no exception and they are required to possess the qualities and skills to increase students' knowledge and proficiency in physical activities during classes.

Effective teaching depends on classroom instructional and management skills. Doyle (1986) have identified that teaching involves a combination of learning and maintaining order. They are mainly served by instructional and managerial functions. 
Physical educators demonstrated that teachers' instructional technique (Kwak, 1993; Landin ,1994; Rink, 1994), feedback behaviours (Behets,1997; Pease, 1984; Pellet \& Harrison, 1995; Masser, 1987; Silverman, Tyson, \& Morford, 1988; Xiang \& Lee, 1995) and management skill in class (Downing, 1996; O'Sullivan \& Dyson, 1994) were related to effective teaching and student learning.

\section{Time Variable in Effective Teaching}

It is believed that students learn more when they practice more during physical education lesson. Effective teaching will depend to a certain extent how the teachers allocate time for students to practice in appropriate tasks. Teacher instruction time and teacher management time are the two common time variables that the researcher would like to look into.

Teacher instruction time is defined as the time the teacher uses in presentation, monitoring, and providing performance feedback to the students (Phillips \& Carlisle, 1983). Studies in general teaching and physical education have indicated that an increase in instruction time significantly improved student achievement (Carlisle, 1981; Evertson, Emmer, Brophy, 1980; Good, 1979). Physical educators also revealed that most of the physical education teachers spent over two third of the time in instructional behaviours during teaching. They reported the total instructional time ranged from $70.89 \%$ to $79.96 \%$ (Smith, Kerr, \& Wang, 1993; Laker, 1994; Curtner-Smith, Kerr, \& Henchen, 1995a). It seems that there is common pattern of instructional behaviors in any population of physical education teachers.

Teacher management time is regarded as the time devoted to organization and transition before, during, and subsequent to a teaching lesson (Phillips \& Carlisle, 1983). Beginning and ending class, class organization, equipment organization as well as student behaviour management are within this category. Researchers in physical education and other fields have reported that the decrease of management time can improve student engaged time and enhance student achievement (Emmer \& Evertson, 1981; McLeish, Howe, \& Jackson, 1981). Some investigators also indicated that more effective teachers spent less time in management and increased student's engaged time compared to less effective teachers (Englert, 1983; McLeish et al., 1981).
In classroom practice, teachers spend some considerable time in classroom management. Researchers have indicated the specific teacher management time within the total class time range from 19\%-52\% (Anderson \& Barrette, 1978; Carlisle, 1981; Curtner-Smith, Kerr, \& Hencken., 1995b; Godbout, Brunelle, \& Tousignant., 1983; Laker, 1994; Lacon \& Curtner-Smith, 1998; Phillips \& Carlisle, 1983; Siedentop, Herkowitz, \& Rink., 1984; Shute, Dodds, Placek, Rife, \& Silverman., 1982; Smith, Kerr, \& Wang., 1993). Nevertheless, most physical education teachers on average spent almost one third of the lesson time in classroom management.

\section{Effectiveness and Experience}

School experience has been regarded as one of the essential components in teacher training programmes (Tannehill \& Zakrajsek, 1988). Dodds (1989) suggested that school experience would provide student teachers opportunities to observe and learn how to teach in schools. Educators argued that all teachers with years of experience could, and would, become proficient, or even expert in teaching (Berliner, 1986; Siedentop \& Eldar, 1989; Bell, 1997). Berliner (1988) proposed five stages of skill learning and development of teachers based on those stages suggested by Dreyfus and Dreyfus (1986): (1) novice, (2) advanced beginner, (3) competent, (4) proficient and (5) expert. He suggested that teachers take some time to develop from one stage to another. It seems that experience is a predominant element in effective teaching.

Researchers have been interested in studying the relation between the element of teaching experience to teaching effectiveness. Several studies were conducted to examine the classroom teachers over a long term period, however, the findings were inconclusive (Adams, 1982; Ayers, 1986; Mays, 1989).

The results of some socialization studies indicated that the effects of the work place have changed the teacher effectiveness in physical education (Arrighi \& Young, 1987; Placek, 1984; Schempp, 1986; Templin, 1979, 1981). Zeichner and Tabachnick (1981) justified these ìwash out effectî of teacher education was due to the graduates confronting the reality of the workplace. Dodds (1994) concluded that school teaching environment might influence the teaching competency of the physical education teachers. In other words, school teaching experience has influential effects on teaching behaviours. 
In addition, researchers have found that there are differences in cognitive and teaching behaviours between the experienced and the novice teachers (Levin,1993; Mostert \& Nuttycombe, 1991; Yon , 1991). Similar findings can be obtained in the field of physical education. Experienced teachers had better performance than the novice teachers (Cardoza,1989; Graham, French, \& Woods, 1993; Graham, Hopple, Fortin, 1992; Housner \& Griffey, 1985; Griffey \& Housner, 1991; Manross, \& Sitzman, 1993; Philips \& Carlisle,1983; Stroot \& Morton, 1989).

Recently, Tam (1997) compared the instructional activities of trained/experienced teachers and untrained/ less experienced teachers in the Hong Kong school classroom setting. Results indicated the experienced teachers had better teaching and management skills than the less experienced teacher even they had similarities in the approach of teaching. Tam suggested that training and experience did produce relatively more effective teaching behaviours.

Ha (1996) also examined teachers behaviours in Hong Kong secondary school physical education setting. She compared the teaching feedback pattern of forty pre-service and in-service teachers by using the SelfAssessment Feedback Instrument (Mancini \& Wuest, 1989). Results showed that the in-service group had significantly higher percentages of using teaching feedback of praise, praise/re-instruct and questioning than the pre-service group. She concluded that teachers with more experience seemed could attend to more information which would be used to deal with more details when teaching. It is likely that experience could make a difference to some teaching behaviours between the pre-service and in-service teachers.

On the whole, the research findings are mixed, but it seems that having more in field teaching experience may alter the pedagogical knowledge and teaching behaviours of the teacher. If this assumption is true, there should be differences in teaching behaviours between the inservice and pre-service student teachers since the inservice group has more in field teaching experience. As there are few studies investigating the teaching behaviours of Hong Kong in-service and pre-service primary physical education student teachers, it is worthwhile to start looking into this issue. The purposes of this study are twofold: (1) to analyze the teaching behaviours of the pre-service and in-service primary physical education student teachers and (2) to examine whether there are differences between their teaching behaviours. The information given in this study help to understand more of the pre-service and in-service primary physical education student teachers' teaching performance. This is useful to the physical education teacher educators when they supervise student teachers during the teaching practice.

\section{Method}

\section{Subjects}

The participants were two groups of students seeking teacher certification in primary physical education at an institution of education in Hong Kong. One group consisted of pre-service student teachers engaged in the final year of a two-year full time programme. While the other group consisted of in-service student teachers enrolled in the final year of a three-year part time programme. Upon examination the goals and content, it can be argued that there are no significant differences in two programmes. Thus, it is assumed that the in-service primary physical education student teachers receive the same training as the pre-service primary physical education student teachers do. The major difference is that the in-service group have more in field teaching physical education experience since they have to teach daily in their own schools. In fact, their teaching experience ranged from three to seven years with an average of 4.88 . While the preservice group have limited in field teaching physical education experience, having only six week of teaching practice experience in general subjects in the first year and eight-week practicum of physical education and general subjects during the final year.

\section{Procedures}

During their methods classes in physical education, as the subject lecturer, the researcher briefly introduced the outline of the proposed study. Twenty student teachers of both in-service and pre-service groups were randomly selected and invited to participate in the study. However, eight in-service and three pre-service student teachers showed no interest and declined the invitation. Three reserved pre-service student teachers filled up the places while the remains of the in-service group did not wish to participate in the study. Subsequently, twenty preservice and twelve in-service student teachers met again for further clarification and discussion about the conduct of the study. 
To insure protection and to gain the trust of the participants, confidentiality and anonymity were guaranteed concerning the collection of data and the report of study. Erickson (1986) commented that these procedures help to lower risk (social, physical or psychological) for the subjects and address the ethical issues of paradigmatic research.

Both groups of student teachers were requested to videotape two teaching lessons of physical education during their teaching practice period. The pre-service group were advised to record their lessons within the last three weeks of their teaching practicum, while the in-service group were asked to videotape their lessons during the last semester of their teacher education programme. This is to ensure they both have attended the methodology and didactic courses as well as gaining full advantage of the student teaching experience. Consent for participation were gained from school principals and from all subjects. The participants were assured that all data collected would be confidential and in no way affect their grade for the student teaching performance. They were strongly requested to use their normal teaching methods during the videotaped lessons. Student teachers were reminded to explain to the class on the first day the video camera was in class that the recorder was assisting in a research project studying the teaching behaviours of the teacher. The video camera was brought into the class one lesson before the start of data collection to help minimize the effect of reactivity with students. The participants were not told the purpose of the study until after the complete videotaping of their lessons.

Sixty-four of the lessons videotaped were taught to pupils from primary three to primary six. For the interest of the researcher and the purpose of unifying the teaching contents, the activities taught in the lessons were limited to ball games activities. Activities taught by the in-service student teachers during videotaped lessons were basketball (11 lessons), football (7 lessons) and volleyball (6 lessons). The pre-service student teachers taught the same three types of game activities: basketball (14 lessons), football (14 lessons) and volleyball (12 lessons). It was hypothesized that this kind arrangement would minimize possibly variation of their teaching behaviours in different ball games lessons.

Equipment supply for teaching activities appeared to be adequate. The sport facilities for physical education lesson in each school included one basketball court, one covered playground and some leisure spaces. It was also hypothesized that the sport facilities and equipment in each school would not influence the teaching behaviours of the student teachers at any major degree.

All lessons were videotaped by using a videotape camera placed in a location which did not interfere with the normal teaching of the lessons. Videotaping started when the teacher and the first student entered the playing area and continued until the students were dismissed.

\section{Systematic Observation Instrument}

The videotape of each lesson was coded for teacher instruction time and teacher management time using the revised version of the Physical Education Teacher Assessment Instrument (PETAI) (Phillips, Carlisle, Steffen, \& Stroot, 1986). This instrument helps to capture how the teacher spends the allocated time in the use of different instructional and managerial teaching behaviours.

The PETAI allows for a continuous temporal recording of two categories of teacher behaviours, the instructional and the managerial behaviours. There are five teacher instructional behaviours and five teacher managerial behaviours within the PETAI. The five teacher instructional behaviours are planned presentation (PP), response presentation (RP), monitoring $(\mathrm{M})$, performance feedback $(\mathrm{PF})$, and motivational feedback (MF). The five teacher managerial behaviours are beginning/ending class (BEC), equipment management $(\mathrm{EM})$, organization $(\mathrm{O})$, behaviour management $(\mathrm{BM})$, and other tasks (OT). The definitions of these behaviours and examples are shown in Table 1.

The main measure of validity of the PETAI involves of content validity. The behaviours of the PETAI and their respective subparts have been explicitly defined and observed in all types classroom setting including formal physical education lessons. Phillips and Carlisle (1983) state further that the categories of the instrument have been identified in extensive teacher effectiveness literature. The clearness of the behaviour categories and the easy comprehensible examples given by this instrument have increased its validity (Dunkin \& Biddle, 1974). The continuous recording of data of PETAI has given high representation of the data, which in turn provides additional support for the validity of the instrument. 
The amount of time spent in each teacher behaviour category was recorded in minutes and seconds. This information also allowed for transforming into the percentage of lesson time spent in each behaviour category in later stage.

\section{Coding and Observer Reliability}

All coding of the videotapes was done by two research assistants. Observers training to use the PETAI was supervised by the author and involved the coding of videotaped physical education lessons. The main purpose was to develop and refine the coding procedures of the research assistants. In order to establish the accuracy and consistency of the systematic observation procedures, both intra- and inter-observer reliability was checked by using the methods recommended by Van der Mars (1989). Intra- and inter-observer reliability ranged from $94.1 \%$ to $100 \%$ and $83.4 \%$ to $100 \%$ respectively. Both surpassed the acceptable limit of $80 \%$ suggested by Van der Mars.

Table 1. Definitions of the Teacher Instructional and Managerial Behaviours Coded by the Physical Education Teacher Assessment Instrument.

\section{Instructional Behaviours}

Planned Presentation (PP): The time utilized to present planned instructional material to the pupils. Examples: (1) "The subject of today's lesson is ..." (2) "Today we will begin work on the forehand drive."

Response Presentation ( $\mathbf{R P})$ : The time utilized to restate, emphasize, or summarize information relative to the aspects of a performance. Example: (1) "Let me explain the main teaching points to you again ..." (2) "Remember everyone, keep your eye on the ball."

Monitoring (M): The time utilized to observe the learning environment. This may include some incidental talk. Examples: (1) The pupils are engaged in a practice and the teacher watches the whole class from the side of the playing field. (2) The teacher watches one pupil throw a javelin.

Performance Feedback (PF): The time utilized to provide information relative to the aspects of a performance that is specific to the immediate execution of a skill. Examples: (1) "Make sure you pick the bat before the bowler releases the ball." (2) "Your decision to move to the net following that approach was correct."

Motivational Feedback (MF): The time utilized to provide general responses to a skill attempt. Examples: (1) "Well done." (2) "Brilliant attempt."

Teacher Instructional Time (TIT): The total time the teacher utilizes to present, monitor, and provide feedback to the pupils and the sum of PP, RP, M, PF, and MF.

\section{Managerial Behaviours}

Beginning/Ending Class (BEC): The time utilized to begin the lesson, record tasks, and to end the lesson. Examples: (1) The teacher checks that all the pupils in the class are present. (2) The teacher sends groups of pupils into the changing room at the end of a lesson.

Organization $(\mathrm{O})$ : The time utilized to organize for skill development or game play. Examples: (1) The teacher organizes the class into groups for a new practice. (2) " get into pairs as quickly as you can."

Equipment Management (EM): The time utilized to obtain, set up, distribute, or collect equipment. Examples: (1) The teacher passes out tennis balls to the pupils. (2) The teacher places cones on the playing field in order $t$ mark areas for the practice of different skills.

Behaviour Management (BM): The time utilized to provide feedback relative to pupil behaviour. Examples: (1) The teacher reprimands a pupil for off task behaviour. (2) The teacher speaks to a pupil who arrives late for a lesson.

Other Tasks (OT): The time utilized for purposes other than class management or instruction. Examples: (1) The teacher stops monitoring the class to converse with the headteacher. (2) The teacher attends to a pupils who has been injured.

Teacher Management Time (TMT): The total time the teacher is engaged in class organization, not directly related to teacher instruction time and the sum of BEC, EM, O, $\mathrm{BM}$, and OT. 


\section{Statistical Analysis}

Data generated by the PETAI coding procedure were entered into a SPSS (Statistical Package for the Social Science) programme for statistical analysis. Descriptive statistics including the mean and standard deviation were calculated for all behavior category of the observation instrument. These descriptive data allowed comparing with the results of other studies in this area. Independent ttest for each behaviour category were employed to examine whether there were differences in the amount of time spent between the pre-service and in-service groups. A significance level of 0.05 (two tailed) was established for all test analyses.

\section{Resullts}

\section{Student Teachers}

The mean percentage and standard deviations of time spent in the various teacher behaviours of the PETAI by the 32 student teachers in 64 lessons are presented in Table 2. The student teachers spent $77.19 \%$ of their time in instructional behaviours and $22.81 \%$ of their time in managerial behaviours. Table 2 also shows that they spent $11.52 \%$ of their time giving performance feedback, $0.19 \%$ of the time providing motivational feedback, and $15.24 \%$ of their time emphasizing, reminding student the major teaching points. Moreover, they also allocated $12.98 \%$ of their time explaining and giving demonstrations of the skill practices and game application, and $37.26 \%$ of their time passively observing student practice and learning.

The student teachers allocated much less time in management activities. The analysis of the student teachers' management time indicates that they spent $10.44 \%$ in equipment set up and handling, $0.17 \%$ of their time to begin and end lessons, and $0.18 \%$ of their time to complete tasks other than instruction or management. Besides, the student teachers spent $0.67 \%$ managing pupils' behaviours and $11.35 \%$ of their time organizing the class for learning.

Table 2. Percentages of Teacher Behaviour Time for the Thirty-two Student Teachers in Sixtyfour Lessons.

\begin{tabular}{|c|c|c|c|c|}
\hline Behaviour & Mean\% & Standard Deviation & Low Score & High Score \\
\hline \multicolumn{5}{|l|}{ Instructional } \\
\hline \multicolumn{5}{|l|}{ Behaviours } \\
\hline PP & 12.98 & 5.19 & 5.50 & 30.30 \\
\hline RP & 15.24 & 8.43 & 3.10 & 32.60 \\
\hline
\end{tabular}

\begin{tabular}{ccccc} 
M & 37.26 & 9.07 & 20.40 & 57.20 \\
PF & 11.52 & 6.32 & 2.70 & 30.80 \\
MF & 0.19 & 0.32 & 0.00 & 1.40 \\
TIT & 77.19 & 9.58 & 52.90 & 96.30 \\
Managerial & & & & \\
Behaviours & & & & \\
BEC & 0.17 & 0.43 & 0.00 & 2.1 \\
EM & 10.44 & 6.48 & 0.80 & 26.10 \\
O & 11.35 & 5.94 & 2.00 & 26.90 \\
BM & 0.67 & 1.31 & 0.00 & 5.70 \\
OT & 0.18 & 0.62 & 0.00 & 3.50 \\
TMT & 22.81 & 9.59 & 3.70 & 47.10 \\
& & & & \\
\hline
\end{tabular}

\section{Pre-service and In-service}

The mean percentages and standard deviations of time spent in the various instructional and managerial behaviours by the pre-service and in-service student teachers are shown in Table 3. For the pre-service student teachers, behaviour of monitoring received the highest percentage with $38.29 \%$ whilst motivation feedback was the lowest percentage with $0.22 \%$ within the instructional behaviours category. Of the managerial behaviours category, the pre-service student teachers spent mostly the time on activities organization with $13.03 \%$, whilst the least time on beginning and ending class with $0.25 \%$. For the in-service student teachers, behaviour of monitoring received the highest percentage with $35.27 \%$ whilst planned presentation was the lowest percentage with $0.14 \%$ within the instructional behaviours category. Of the managerial behaviours category, the in-service student teachers spent mostly the time on activities organization with $8.82 \%$, whilst the least time on beginning and ending class as well as tasks not related to instruction with $0.06 \%$.

Table 3. Percentages of Teacher Behaviour Time for the Pre-service and In-service Student Teachers in Sixty-Four Lessons

\begin{tabular}{|c|c|c|c|c|c|c|}
\hline Behaviour & Pre-service & $N=40$ & In-service & $N=24$ & & \\
\hline & Mean \% & $\mathrm{SD}$ & Mean \% & SD & $\mathbb{t}$ & $\mathrm{p}$ \\
\hline \multicolumn{7}{|l|}{ Instructional } \\
\hline \multicolumn{7}{|l|}{ Behaviours } \\
\hline PP* & 14.01 & 5.47 & 11.28 & 4.28 & 2.09 & 0.041 \\
\hline $\mathrm{RP} *$ & 10.32 & 5.12 & 23.06 & 6.64 & -8.60 & 0.000 \\
\hline M & 38.29 & 8.44 & 35.27 & 9.92 & 1.29 & 0.199 \\
\hline $\mathrm{PF}$ & 10.33 & 4.69 & 13.53 & 8.08 & -1.77 & 0.086 \\
\hline MF & 0.23 & 0.37 & 0.14 & 0.20 & 1.07 & 0.285 \\
\hline TIT** $^{*}$ & 73.18 & 9.14 & 83.28 & 6.23 & -5.42 & 0.000 \\
\hline \multicolumn{7}{|l|}{$\begin{array}{l}\text { Managerial } \\
\text { Behaviours }\end{array}$} \\
\hline $\mathrm{BEC}$ & 0.25 & 0.49 & 0.06 & 0.26 & 1.93 & 0.058 \\
\hline
\end{tabular}




$\begin{array}{ccccccc}\text { EM* }^{*} & 12.29 & 7.03 & 7.63 & 4.15 & 3.32 & 0.001 \\ \mathrm{O}^{*} & 13.04 & 6.25 & 8.82 & 4.35 & 2.90 & 0.005 \\ \text { BM* }^{*} & 0.98 & 1.53 & 0.15 & 0.53 & 3.15 & 0.003 \\ \text { OT } & 0.26 & 0.76 & 0.06 & 0.21 & 1.49 & 0.142 \\ \text { TMT }^{*} & 26.82 & 9.11 & 16.72 & 6.24 & 4.99 & 0.000\end{array}$

$\mathrm{N}=64 ; * \mathrm{p}<.05$

Statistical analyses revealed that in-service group had significantly $(\mathrm{p}<.05)$ higher percentages of time spent on response presentation as well as the total time in class instruction than the pre-service group. Moreover, results also indicate that pre-service group had significantly $(p<.05)$ higher percentages of time spent on planned presentation, equipment management, activities organization, behaviour management as well as the total time in class management than the in-service group.

\section{Discussions}

Physical educators have identified proper allocation of time in instructional and managerial behaviours would help student learning in physical education lessons. CurtnerSmith (1994) has demonstrated that teachers who spend relatively large proportion of lesson time in instruction and relatively less time in class management are more successful in terms of enhancing students skill learning. Other physical educators also agree if teachers can spend a minimum of time in managerial behaviour and make use of the time to provide short and explicit demonstration with appropriate information would help student to have more time in skill practising and learning (Byra \& Coulon, 1994; Silverman, 1991). Metzler (1989) after reviewing researches on sport pedagogy and commented that most American physical educators spent a lot of time to noninstructional activities and allocated about 25 to $50 \%$ of their lesson time in management, passively observing and organizing. Relatively speaking, the student teachers in the present study have demonstrated good teaching behaviours in terms of time spent of both instructional and managerial behaviours. They allocated most of their lesson time in instructional behaviours with $77.19 \%$ and only $22.81 \%$ in managerial behaviours.

When comparing the student teachers behaviours with recent researches using PETAI to investigate teacher behaviours (Aicinena, Steffen, \& Curtner-Smith, 1992; Curtner-Smith, Kerr, \& Hencken, 1995a, 1995b; Lacon \& Curtner-Smith, 1998; Smith, Kerr, \& Wang, 1993), the local sample have spent relatively more lesson time in instructional behaviours and relatively less lesson time in managerial behaviours than all the other American and English physical education teachers. Moreover, they spent rather short time in presenting their teaching materials. This might be due to the short lesson time in Hong Kong primary school. The normal primary physical education lesson time in Hong Kong range from 30 to 35 minutes. This will not permit them to have a long explanation and demonstration during the lesson.

Besides, the local student teachers also allocated relative more time in response presentation and reasonable time in performance feedback. This indicated that they kept repeating and reminding the teaching points as well as providing information with response to the skill performance of the students, which were always emphasized by the institute supervisors. However, it was discouraging to know that they did not give much motivational feedback. Motivational feedback is helpful to encourage student learning. The possible explanation is due to their inadequate teaching experience as they are at the novice stage of teacher development according to the Berliner (1988). The teachers were inflexible and labeling every task they have learnt from the teacher education institute. They could only concentrate on the contents presentation and neglect the learning of the individual student. In fact, Ha (1996) also obtained similar results when she examined the teaching behaviours of 40 Hong Kong physical educators. They provided low rates of praise and corrective to positive feedback when teaching physical education lessons.

Providing feedback to students is the major immediate task of school teachers. Effective teachers usually allocate large amount of time in helping student skill acquiring by giving performance feedback, motivational feedback and response presentation (Knop, 1986; Phillips \& Carlisle, 1983;). It appeared that the local student physical education teachers had spent considerable time in helping students to learn except giving less attention to individual student performance.

It should be noted that the management time was commendably low. When comparing the management time of the present sample to the American and British physical educators, it is encouraging to know that the local student teachers spent comparatively less time in class management. As Brophy (1982) pointed out that one of the characteristics of effective teachers was minimizing time spent on class management activities. It seemed that the Hong Kong student teachers were doing very good jobs in this aspect. 
In addition, the in-service student teachers also demonstrated that they were more effective than the pre-service group in terms of time spent in the lesson. They had spent significantly more time in instructional behaviour and significantly less time in managerial behaviour than the pre-service student teachers.

Within the instructional behaviours, the in-service group had given significantly more response presentation time than the pre-service group. They emphasized giving teaching points and summarizing information relative to the skill learning activities. They gave more attention to student performance by giving more time in performance feedback than the pre-service group. However, they did not exhibit positive feedback and share a low percentage of time in motivational feedback as with the pre-service counterparts. It is likely that the inservice student teachers were more concerned about the individual student performance. Having more in field teaching experience seemed to be the only possible means that helped the in-service group move to a more mature stage of teacher development. As they have four to seven year teaching physical education experience, according to Berliner (1988), they might enter into the stage of advance beginner and competent. They are more aware student performance, able to make conscious choices about their actions as well as more flexible in teaching. Instead of just presenting the skill activities, they know how to help student learning by giving more skill related and performance feedback.

Furthermore, the pre-service group spent significantly more time in planned presentation than the in-service counter part. This indicated that they took more time in explaining and demonstrating their teaching contents than the in-service group. As there is limited time in primary school lesson, it is not advisable to allocate too much time in verbal information nor demonstrations. Behets (1997) showed that the most effective teachers gave less instructional information and less time on demonstrations. The pre-service group is likely not teaching as effective as the in-service group.

In terms of class management, the in-service group seemed to have better management skills than the preservice counterparts as they had significantly less managerial time. Siedentop, Herkowitz, and Rink (1984) claimed that a major goal of good teaching is to reduce management time. They further pointed out that student teachers could develop into good class managers and spend no more than $10 \%$ in management time. In a study of 18 experienced physical educators, Phillips and Carlisle (1983) found the most effective teacher spent an average of $12.09 \%$ of class time in management. Research studies indicated that many primary school physical education teachers were ineffective and spent large percentage of time in management (Quarterman, 1977; Stewart, 1980). The primary physical educators on average allocated $37 \%$ of the lesson time in management and the least effective teacher even spent $52 \%$ of the lesson time in these studies. In the present study, in-service student teachers share low percentage class management time as $16.72 \%$. It seems that they are managing the class very well.

When inspecting the managerial behaviours carefully, the in-service student teachers spent significantly less time in equipment management, organization and behaviour management than the pre-service student teachers. They are more efficient in handling equipment set up and distribution. They also demonstrate active skills in organizing learning activities as well as managing students behaviours. It is possible that by gaining more in field teaching experience they know their students better and learn how to plan and handle the classes more wisely.

The in-service group indeed has more opportunities to refine their teaching than the pre-service counterparts. They have more chance to consult their colleagues' comments and share ideas for improving their teaching performance in school. Besides, they did have more supervision advice from their institute supervisors as they had teaching supervision every year. They had more opportunities on reflection for their teaching performance. Biggs and Moore (1993) suggest that student teachers would benefit if they are allowed reflection and absorption of their teaching experience. Teaching experience, reflective practice and constructive teaching supervision advice did enhance in-service student teachers teaching performance.

\section{Implications}

The results in the present study revealed that the student teachers did not give much motivational feedback. This information would help the teacher educators when teaching the methodology courses. Moreover, there is still room for the pre-service student teachers to improve their classroom management time. It seems that the pre-service student teachers lack of pedagogical skills with related to classroom 
management. Development of these abilities should be emphasized within the pre-service teacher education programme in future.

Data generated support that the in-service student teachers have better teaching performance than the preservice counterparts. This implies that teaching experience is vital to the development of effective teaching. Graham (1990) comments that there is no substitute for spending time with real children, in real schools and with real teachers. Other educators even point out that improved classroom practicum experienced accelerated novice teachers' growth toward expert pedagogy (McDermott, Gormley, Rothenberg, \& Hammer., 1995). Teacher educators in Hong Kong should revise the pre-service student physical education training programmes and extend their opportunities and experience in teaching physical education. In addition to organize more peer teaching trials, the time duration and frequency for the teaching practicum should be increased. Providing more chance in practice teaching may help the student teachers to shorten their journey from novice to competent level.

Since the teaching performance of the pre-service and in service student teachers are different, the teacher educators should re-consider the different needs and concerns of these two groups of student teachers in their teaching practicum. More appropriate advices could be addressed during their teaching supervision.

The findings of the present study did provide some information on teaching behaviours of student teachers in primary physical education. This investigation provides new direction for the Hong Kong physical education researchers. By conducting more study on teaching behaviours in primary physical education teachers, we will understand more about the teaching of the Hong Kong primary physical education teachers.

\section{Conclusion}

To conclude, there were significant differences in instructional and managerial behaviours between the preservice and the in-service primary physical education student teachers. In term of time spent, the in-service student teachers seem to perform better than their preservice counterparts. Such a difference might be attributed to the in-service subjects with more in field teaching experience. This support the notion that the in field experience is a vital component of effective teaching. There is no short cut from novice to expert. The findings are invaluable to teacher educators when they develop the teacher education programmes as well as supervising the student teachers during their teaching practice.

This study, of course, involves a limited sample, and more research with greater sample size in different teacher training institutes is needed to determine whether these results can be generalized to other student teachers. In future study, there is a need to further examine what factors contribute to the differences of their teaching behaviours. Since teaching is a complex dynamic activity occurring in a complex environment (Shulman, 1987), quantitative data alone could not give a full account of the teaching behaviours of the student teachers. Qualitative data should also be collected in order to get a more in-depth understanding of what the student teachers do during their teaching. If we continue to gain more insight and information of the teaching behaviours of the pre-service and in-service student teachers, we may be able to establish the shortest route in developing teaching competent for the student teachers in near future.

\section{References}

Adams, R. D. (1982). Teacher development: A look at changes in teacher perceptions and behaviours across time. Journal of Teacher Education, 23(4), 40-43.

Aicinena, S. T., Steffen, J. P., \& Curtner-Smith, M. D. (1992). A comparison of the behaviours of physical education teachers in curricular and extra-curricular settings. Physical Education Review, 15(2), 148-156.

Anderson, W. G., \& Barrette, G. T. (Eds.). (1978). What's going on in gym: Descriptive studies of physical

education classes. Motor Skill: Theory Into Practice, Monograph 1.

Arrighi, M. A., \& Young, J. C. (1987). Teacher perceptions about effective and successful teaching. Journal of Teaching in Physical Education, 6(2), 122-135.

Ayers, J. B. (1986). Teacher education program evaluation: A case study past and future. (ERIC Document Reproduction Service No. ED 275669).

Behets, D. (1997). Comparison of more and less effective teaching behaviours in secondary physical education. 
Teaching and Teacher Education, 13,215-224.

Bell, M. (1997). The development of expertise. Journal of Physical education, Recreation and Dance, 68(2), 34-38.

Berliner, D. C. (1986). In pursuit of the expert pedagogue. Educational Researcher, 15(7), 5-13.

Berliner, D. C. (1987). Simple views of classroom teaching and a simple theory of classroom instruction. In D. Berliner \& B. Rosenshine (Eds.), Talks to teacher (pp. 93-110). New York: Random House.

Berliner, D. C. (1988). The development of expertise in pedagogy. (ISBN-0-89333-053-1) Washington, DC; American Association of Colleges of Teachers Education. (ERIC Document Reproduction Services No. ED 298122).

Biggs, J. B., \& Moore, P. J. (1993). The process of learning ( $3^{\text {rd }}$ ed.). New York: Prentice Hall.

Brophy, J. E. (1982). Successful teaching strategies for the inner-city child. Phi Delta Kappan, 63, 527-530.

Byra, M., \& Coulon, S. C. (1994). The effect of planning on the instructional behaviours of pre-service teachers. Journal of Teaching in Physical Education, 13(2), 123-139.

Cardoza, P. L. (1989). Describing teacher-student interaction and teaching effectiveness of student, novice and experienced physical education teachers $K-3$ [CD-ROM]. Abstract from: ProQuest File: Dissertation Abstracts Items: 8918165.

Carlisle, C. (1981). An analysis of the relationship between selected teacher process variables, selected skill learning time variables, and student achievement in physical education classes, grades five through eight. Unpublished doctoral dissertation, University of Colorado, Boulder, CO.

Curtner-Smith, M. D. (1994). Management of the physical education environment. Physical Education Review, 17(2), 117-125.

Curtner-Smith, M. D., Kerr, I. G., \& Hencken, C. L. (1995a). The impact of national Curriculum Physical Education on teachers' behaviours related with pupils' skill learning: A case study in One English town. British Journal of Physical Education Research Supplement, 16,20-27.

Curtner-Smith, M. D., Kerr, I. G., \& Hencken, C. L. (1995b). Teacher behaviours related with pupil psychosocial development in physical education: A descriptiveanalytic study. Educational Research, 37(3), 267-277.

Dodds, P. (1989). Trainees, field experiences, and socialization into teaching. In T. J. Templin, \& P. G. Schempp (Eds.), Socialization into physical education: Learning to teach (pp. 81-104). Indianapolis: Benchmark Press.

Dodds, P. (1994). Cognitive and behavioral components of expertise in teaching physical education. The Quest, $46(2), 153-163$.

Downing, J. H. (1996). Establishing a discipline plan in elementary physical education. Journal of Physical Education, Recreation and Dance, 67(6), 25-30.

Doyle, W. (1986). Classroom organization and management. In M. C. Wittrock (ed.), Handbook of research on teaching ( $3^{\text {rd }}$ ed., pp. 392- 431). New York: Macmillian.

Dreyfus, H. L., \& Dreyfus, S. E. (1986). Mind over machine. New York: Free Press.

Dunkin, M. J., \& Biddle, B. J. (1974). The study of teaching. New York: Holt, Rinehart \& Winston.

Emmer, E., \& Evertson, C. (1981). Synthesis of research on classroom management. Educational Leadership, $38(4), 342-347$.

Englert, C. S. (1983). Measuring special education teacher effectiveness. Exceptional Children, 50(3), 247-254.

Erickson, F. (1986). Qualitative methods in research on teaching. In M.C. Wittrock (Ed.), Handbook of Research on Teaching (pp.119-161). New York: Macmillan.

Evertson, C. M., Emmer, E. T., \& Brophy, J. E. (1980). Predictors of effective teaching in junior high mathematics classroom. Journal for Research in Mathematics Education, 7(3), 167-178.

Fortin, S. (1992). The teaching of modern dance: What two experienced teachers know, value, and do. Unpublished doctoral dissertation, The Ohio State University, Columbus, $\mathrm{OH}$.

Godbout, P., Brunelle, J., \& Tousignant, M. (1983). Academic learning time in elementary and secondary physical education classes. Research Quarterly for Exercise and Sport, 54(1), 11-19.

Good, T. L. (1979). Teacher effectiveness in the elementary school. Journal of Teaching Education, 30, 52-64. 
Graham, G. (1990). The development physical education teacher and coach: Empirical and research insights. In M. Lirette, C. Pare, J. Dessureault, \& M. Pieron (Eds.), Physical education and coaching: Proceedings of the 1987 AIESEP World Convention (pp. 87-99). Sillery, PQ: University of Quebec Press.

Graham, G., Hopple, C., Manross, M., \& Sitzman, T. (1993). Novice and experienced children's physical education teachers: Insight into their situation decision making. Journal of Teaching in Physical Education, 12(2), 197-214.

Graham, K. C., French, K. E., \& Woods, A. M. (1993). Observing and interpreting teaching-learning process: Novice PETE students, experienced PETE students, and expert teacher educators. Journal of Teaching in Physical Education, 13(1), 46-61.

Griffey, D. C., \& Housner, L. D. (1991). Differences between experienced and inexperienced teacher's planning decisions, interactions, student engagement, and instructional climate. Research Quarterly for Exercise and Sport, 62(2), 196-204.

Ha, S. C. (1996). A descriptive study of pre-service and in-service physical educators' teaching behaviours in Hong Kong. Education Journal, 24(2), 45-56.

Housner, L. D., \& Griffey, D. C. (1985). Teacher cognition: Differences in planning and interactive decision making between experienced and inexperienced teachers. Research Quarterly for Exercise and Sport, 56(1), 45-53.

Knop, P. De. (1986). Relationship of specified instructional teacher behaviours to student gain on tennis. Journal of Teaching in Physical Education, 5(1), 71-79.

Kwak, E. C. (1993). The initial effects of various task presentation conditions on students' performance of the lacrosse throw (motor skill instruction). Dissertation Abstracts International, 54/07, 2507.

Lacon, S. A., \& Curtner-Smith, M. D. (1998). Behaviours of inner-city teachers following the introduction of National Curriculum Physical Education: A descriptiveanalytic study. The Physical Educator, 55(2), 101111.

Laker, A. (1994). Effective teaching behaviours of physical education student teachers. The Bulletin of Physical Education, 30(3), 54-64.

Landin, D. (1994). The role of verbal cues in skill learning. The Quest, 46(3), 299-313.
Levin, B. B. (1993). Using the case method in teacher education: The role of discussion and experience in teachers' thinking about cases [CD-ROM]. Abstract from: ProQuest File: Dissertation Abstract Item: 9430581.

Mancini, V. H., \& Wuest, D. A. (1989). Self-Assessment Feedback Instrument. In P. W. Darst., D. B. Zakrajsek., \& V. H. Mancini (Eds. ), Analyzing physical education and sport instruction (pp. 143-148). Champaign, IL: Human Kinetics.

Masser, L. (1987). The effect of refinement on student achievement in a fundamental motor skill in grades $\mathrm{K}$ through 6. Journal of Teaching in Physical Education, 6(2), 174-182.

Mays, A. R. (1989). Case studies of physical education students from a research based preparation program. Unpublished doctoral dissertation, University of South Carolina, Columbia.

McDermott, P., Gormley, K., Rothenberg, J., \& Hammer, J. (1995). The influence of classroom practica experiences on student teachers' thoughts about teaching. Journal of Teacher Education, 46(3), 184-191.

McLeish, J., Howe, B., \& Jackson, J. (1981). Effective teaching in physical education. Unpublished paper. Faculty of Education, University of Victoria, B. C.

Metzler, M. W. (1989). A review of research on time in sport pedagogy. Journal of Teaching in Physical Education, 8(1), 87-103.

Mostert, M. P., \& Nuttycombe, D. G. (1991, November). Prospective teachers' perception of a teaching episode. Revised version of a paper presented at the Annual Meeting of the Northeastern Educational research Association, Ellenville, NY. (ERIC Document Reproduction Service No. ED 350293).

O’ Sullivan, M., \& Dyson, B. (1994). Rules, routines, and expectations of 11 high school physical education teachers. Journal of Teaching in Physical Education, 13(4), 361-374.

Pease, P. (1984). A comparison of student teachers with and without prior field experience and the effect on criterion process variables during student teaching. Abstract of Research Papers, Reston, VA: AAHPERD.

Pellet, T., \& Harrison, J. (1995). The influence of refinement on female junior high school student's volleyball practice success and achievement. Journal of Teaching in Physical Education, 15(1), 41-52. 
Phillip, D. A., \& Carlisle, C. (1983). A comparison of physical education teacher categorized as most least effective. Journal of Teaching in Physical Education, 2(3), 55-67.

Phillips, D. A., Carlisle, C., Steffen, J., \& Stroot, S. (1986). The computerized version of the physical education assessment instrument. Unpublished manuscript. University of Northern Colorado, Greeley, CO.

Placek, J. (1984). A multi-case study of teacher planning in physical education. Journal of Teaching in Physical Education, 4(1), 39-49.

Quarterman, J. (1977). A descriptive analysis of physical education teaching in the elementary school. Unpublished doctoral dissertation, The Ohio State University, Columbus, $\mathrm{OH}$.

Rink, J. R. (1994). Task presentation in pedagogy. The Quest, 46(3), 270-280.

Rosenshine, B. (1987). Explicit teaching. In D. Berliner \& B. Rosenshine (Eds.), Talks to teacher (pp. 7592). New York: Random House.

Schempp, P. G. (1986). Physical education student teachers' beliefs in their control over student learning. Journal of Teaching in Physical Education, 5(3), 198-203.

Shulman, L. (1987). Knowledge and teaching: Foundations of the new reform. Harvard Educational Review, 57, $1-22$.

Shute, S., Dodds, P., Placek, J., Rife, F., \& Silverman, S. (1982). Academic learning time elementary school movement education: A descriptive analytic study. Journal of Teaching in Physical Education, 1(2), 3-14.

Siedentop, D., \& Eldar, E. (1989). Expertise, experience, and effectiveness. Journal of Teaching in Physical Education, 8(2), 254-260.

Siedentop, D., Herkowitz, J., \& Rink, J. (1984). Elementary physical education methods. Englewood Cliff, NJ: Prentice-Hall Inc.

Silverman, S. (1991). Review on teaching in physical education: Review and commentary. Research Quarterly for Exercise and Sport, 62(4), 351-364.

Silverman, S., Tyson, L., \& Krampitz, J. (1992). Teacher feedback and achievement in physical education: Interaction with student practice. Teaching and Teacher Education, 8(4), 333-344.
Silverman, S., Tyson, L., \& Morford, L. M. (1988). Relationships of organization, time, and student achievement in physical education. Teaching and Teacher Education, 4(3), 247-257.

Smith, M. D., Kerr, I, G., \& Wang, M. Q. (1993). British physical education teacher behaviours: a descriptive -analytic study. British Journal of Physical Education Research Supplement, 13, 15-21.

Stewart, M. (1980). Teaching behaviours of physical education teachers in the natural environment. College Student Journal, 14, 76-82.

Stroot, S., \& Morton, P. J. (1989). Blueprints for learning. Journal of Teaching in Physical Education, 8(3), 213222.

Tam, P. T. K. (1997). Novice and experienced teachers' instructional activities in the classroom. Educational Research Journal, 12(1), 36-50.

Tannehill, D., \& Zakrajsek, D. (1988). What's happening in supervision of student teachers in secondary physical education. Journal of Teaching in Physical Education, 8(1), 1-12.

Templin, T. J. (1979). Occupational socialization and the physical education student teacher. Research Quarterly, 50(3), 482-493

Templin, T. J. (1981). Student as socializing agent. Journal of Teaching in Physical Education, (Introductory issue), 71-79.

Van der Mars, H. (1989). Observer reliability: Issues and procedure. In P. W. Darst, D. B. Zakrajsek, \& V. H. Mancini (Eds.), Analyzing Physical Education and Sport Instruction (2 ${ }^{\text {nd }}$ ed.) (pp. 53-80). Champaign, IL: Human Kinetics.

Xiang, P., \& Lee, A. (1995). Interaction of feedback and achievement goal during motor skill learning. Research Quarterly for Exercise and Sport, 66, A-72 (Abstract).

Yon, M. G. (1991). The relationship between a year-long student teaching experience and student teachers' schemata for classroom phenomena. Journal of Personnel Evaluation in Education, 5(1), 55-67.

Zeichner, K., \& Tabachnick, R. (1981). Are the effects of university teacher education ìwashed outî by school experience? Journal of Teacher Education, 32(3), 711. 